Quality : Jurnal Kesehatan

Volume 14, Nomor 1 Tahun 2020

pISSN : 1978-4325, eISSN : 2655-2434, DOI: 10.36082/qjk.v14i1.102

\title{
PARTISIPASI MASYARAKAT DALAM PENCEGAHAN PENYAKIT DEMAM BERDARAH DENGUE: SEBUAH TINJAUAN SISTEMATIKA
}

\author{
Lia Meiliyana', Rita Damayanti², Zakianis ${ }^{3}$ \\ 1,2Dep. Pendidikan Kesehatan dan Ilmu Perilaku, Fakultas Kesehatan Masyarakat, Universitas Indonesia \\ ${ }^{3}$ Dep. Kesehatan Lingkungan, Fakultas Kesehatan Masyarakat, Universitas Indonesia
}

\begin{tabular}{|c|c|}
\hline Info Artikel & Abstrak \\
\hline $\begin{array}{l}\text { Genesis Naskah: } \\
\text { (kosongkan) }\end{array}$ & $\begin{array}{l}\text { Demam Berdarah Dengue (DBD) merupakan penyakit yang masih menjadi permasalahan global, karena } \\
\text { tingkat insiden mengalami peningkatan } 30 \text { kali lipat selama } 50 \text { tahun terakhir. Partisipasi masyarakat amat } \\
\text { dibutuhkan dalam keberlangsungan upaya pengendalian DBD. Partisipasi masyarakat membutuhkan } \\
\text { kesadaran diri agar dapat berinteraksi dalam situasi tertentu, dan hal tersebut dipengaruhi beberapa faktor } \\
\text { seperti tingkat pengetahuan dan sikap yang akan membuahkan perilaku yang diharapkan. Penelitian ini }\end{array}$ \\
\hline $\begin{array}{l}\text { Kata Kunci: } \\
\text { Dengue } \\
\text { vector control } \\
\text { Community } \\
\text { participation }\end{array}$ & $\begin{array}{l}\text { menggunakan sistematika review untuk mengkaji upaya pencegahan DBD berdasarkan partisipasi } \\
\text { masyarakat. Strategi pencarian menggunakan } 3 \text { electronic database, EBSCO, Proquest dan Google } \\
\text { Scholar dan mengikuti Protokol PRISMA (Preffered Reporting Items for Systematic Review and Meta } \\
\text { Analyses), dengan periode peenerbitan tahun 2017-2019, didapatkan sebanyak } 17 \text { artikel yang sesuai } \\
\text { dengan kriteria inklusi dan ekslusi. Hasil kajian artikel penelitian didapatkan persentase artikel yang } \\
\text { signifikan pada faktor knowledge rata-rata sebesar 33,4\% artikel, attitude 51,3\% artikel dan practise } \\
33,9 \% \text { artikel, dalam faktor sosiodemografi yang mempunyai kecenderungan sama terdapat pada aspek } \\
\text { pendidikan yaitu sekolah menengah dengan signifikan pada } 42,8 \% \text { artikel. Output tindakan penurunan } \\
\text { angka kejadian DBD pada } 30,8 \% \text { artikel dan indeks entomologis pada } 38,5 \% \text { artikel. kajian mendapatkan } \\
\text { beberapa penelitian tidak memberikan hubungan antara pengetahuan dengan sikap maupun dengan } \\
\text { perilaku positif dalam pencegahan penyakit DBD, tetapi kajian juga mendapatkan metode intervensi pada } \\
\text { partisipasi masyarakat yang dapat menjadi best practise seperti Lansaka Model dan Program Mosquito } \\
\text { Breeding Site Control (MBSC). }\end{array}$ \\
\hline
\end{tabular}

\section{DENGUE PREVENTION THROUGH COMMUNITY PARTICIPATION : SYSTEMATIC REVIEW}

Keywords: Abstract

Dengue Hemorrhagic Fever (DHF) is a disease that is (still) remain a global burden, because the incidence rate has increased 30-fold over the past 50 years. Participation is needed in the ongoing efforts, to control dengue fever. Self-awareness as the main key in participation, influenced by factors such as knowledge, attitudes and behavior. This systematic review is conducted to see dengue prevention efforts based on community participation. Three electronic databases were searched and PRISMA (Preferred Reporting Items for Systematic Review and Meta Analyzes) protocol were followed; and obtained 17 research articles that fit the inclusion and exclusion criteria. The results of the study, The variables have a significant value at 33,4\% of articles from about knowledge factors, $51,3 \% \%$ of articles related attitudes and 33,9\% of articles related to practise. Also, there are 42,8\% of articles significant related to the same level education. Another result are practise output could to be decresed of DHF disease in significant by $30,8 \%$ articles, and enthomologis index by $38,5 \%$ articles. However several study could not show any relation between knowledge, attitude and positive practise also But our studi still found some 
best practise intervention methode of community participation like a Lansaka Model and Mosquito Breeding Site Control (MBSC) programme.

Korespondensi Penulis:

Lia Meiliyana

Jl. Bahari Raya No.6, Jakarta Selatan, email:dr.liameilivana@gmail.com 


\section{Pendahuluan}

Demam Berdarah Dengue (DBD) merupakan salah satu penyakit yang masih menjadi permasalahan global karena tingkat insiden selama 50 tahun terakhir mengalami peningkatan 30 kali lipat (WHO, 2012), setidaknya 400 juta orang terinfeksi virus ini tiap tahun (CDC, 2019). Upaya utama dalam pemberantasan penyakit ini adalah pemutusan rantai penularan virus dengue, walaupun telah tersedia vaksin sejak awal tahun 2016(WHO, 2017). Strategi global dalam pencegahan dan pemberantasan DBD adalah dengan mempromosikan koordinasi multi sektor, pengendalian vektor terpadu, dan keberlanjutan dari program (WHO.int, 2012), dan strategi tersebut sulit dilakukan tanpa adanya respon aktif masyarakat.

Respon aktif masyarakat sebagai bagian partisipasi amat dibutuhkan dalam keberlangsungan upaya pengendalian DBD dengan menjaga lingkungan bersih, mengurangi densitas vektor, melakukan program pemberantasan sarang nyamuk, dan hal tersebut tidak akan terjadi tanpa kesadaran, perubahan perilaku (Glanz, Rimer, \& Viswanath, 2015) dan praktik upaya mencari pertolongan kesehatan di masyarakat. kesadaran diri sendiri kunci utama dalam berpartisipasi. Khusus masalah partisipasi masyarakat, WHO menyusun penanganan DBD dalam "DengueCommunication for Behavior Impact" (DengueCOMBI) (WHO.int, 2012).

Partisipasi masyarakat membutuhkan kesadaran diri agar dapat berinteraksi dalam situasi tertentu. Kesadaran diri dipengaruhi beberapa faktor seperti pengetahuan, dan akan membuahkan sikap dan praktik yang diharapkan. Perilaku yang diharapkan dalam pencegahan penyakit DBD adalah menurunkan kejadian DBD, dan atau vektor penyebabnya.

Salah satu upaya mengukur kesadaran diri adalah dengan menilai perilaku sesuai kesehatan, yang dapat diukur menggunakan variabel-variabel perilaku diantaranya yang sering digunakan adalah penelitian Knowledge, Attitude and Practice (KAP), dan penilaian sosiodemografi, Sehingga Penelitian ini bertujuan mengkaji literatur yang relevan upaya pencegahan DBD pada penelitian partisipasi masyarakat dengan menganalisa dan mencari best practise yang dapat dijadikan acuan pada penelitian lebih lanjut.

(C) Poltekkes Kemenkes Jakarta I

Jl. Wijaya Kusuma No. 47-48 Cilandak Jakarta Selatan, Indonesia email: jurnalquality@poltekkesjakarta1.ac.id

\section{Metode}

Metode yang digunakan adalah sistematika review berdasarkan protokol PRISMA (Preffered Reporting Items for Systematic Review and Meta Analyses) (Shamseer et al., 2016) untuk mengidentifikasikan artikel penelitian yang relevan. Proses pencarian artikel diakses melalui pencarian dari 3 data base elektronik yaitu EBSCO, Pro Quest dan Google Scholar.

Studi kelayakan dilakukan dengan menggunakan kriteria inklusi dan eksklusi. Kriteria inklusi yang ditetapkan penelitian kuantitatif dan mix methode menggunakan data primer, tahun pulikasi (2017-2019), berbahasa Inggris dan Indonesia, artikel dapat diakses secara terbuka (open access), telah melalui tahapan peer review, merupakan artikel full text dan membahas partisipasi masyarakat tentang pencegahan demam berdarah Dengue dengan pengendalian vektor transmisinya. Ekslusi dari tinjauan ini penelitian kualitatif murni, literatur selain artikel, tinjauan literatur, berkaitan dengan vaksinasi, pengobatan medis penderita, surveilance berbasis GIS, modifikasi Iklim, Cuaca dan Kelembaban dan modifikasi fisik. Ekstraksi data dilakukan sesuai dengan flowchat (gambar 1), selanjutnya dilakukan analisis deskiptif naratif terhadap temuan penelitian.

\section{Hasil}

Hasil seleksi berdasarkan keyword dan mengikuti protokol PRISMA didapatkan keseluruhan sejumlah 16.624 artikel, selanjutnya di sreening berdasarkan tahun publikasi (2017-2019) didapatkan sejumlah 5.039 artikel. Screening jurnal berbahasa Inggris yang didapatkan dari Ebsco dan ProQuest; dan berbahasa Indonesia dari Google Schoolar, didapatkan 2.805 artikel. Jurnal open access dengan full text, dan telah melalui tahapan peer review berjumlah 1.475 artikel. Dilakukan studi kelayakan (eligiility) untuk mengeliminasi duplikasi artikel, kurang relevan dengan permasalahan, dan tidak sesuai dengan kriteria inklusi yang ditetapkan. Tahapan terakhir didapatkan sebanyak 17 artikel, yang akan dilakukan analisis. Flowchat dapat dilihat di gambar 1. 


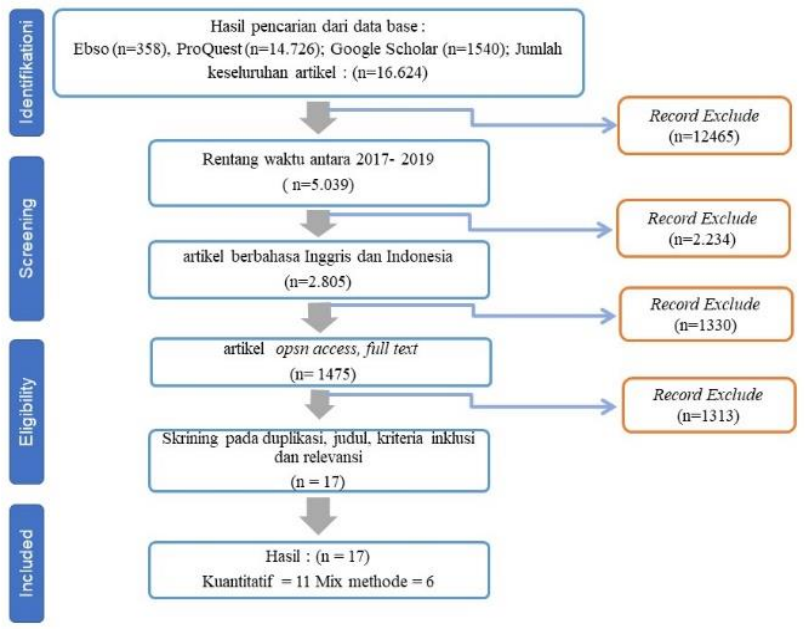

\section{Gambar 1.}

Protokol PRISMA (Preffered Reporting Items for Systematic Review and Meta Analyses) pada partisipasi masyarakat dalam pengendalian vektor

Tabel 1 menggambarkan distribusi faktor-faktor yang digunakan pada penelitian di 17 artikel hasil screening, terdapat variasi penggunaan ke 4 faktor tersebut, seperti faktor sosio demografi dibahas pada 14 penelitian (82,3\%), faktor knowledge, Attitude dan Practise masing-masing 13 penelitian (76,5\%).

Tabel 1. Distribusi artikel berdasarkan faktor yang yang digunakan pada penelitian partisipasi masyarakat

\begin{tabular}{lcc}
\hline \multicolumn{1}{c}{ Variabel } & $\begin{array}{c}\text { Freq. } \\
\text { (artikel) }\end{array}$ & $\begin{array}{c}\text { Persentase } \\
(\mathbf{\%})\end{array}$ \\
\hline Sosiodemografi & 14 & 82,3 \\
Knowledge & 13 & $76,5 \%$ \\
Attitude & 13 & $76,5 \%$ \\
Practise & 13 & $76,5 \%$ \\
\hline
\end{tabular}

Freq : Frekuensi

Jumlah sampel penelitian yang digunakan, dan jumlah kategori item pada aspek-aspek yang dinilai tiap faktor, dijabarkan dalam tabel 2 berikut. Tabel 2 ini menggambarkan jumlah sampel penelitian beragam, dari 40 sampel - 1182 (terbanyak). Item aspek penilaian pada faktor-faktor yang digunakan dalam penelitian partisipasi masyarakat ini beragam, hanya 7 yang menggunakan keempat faktor tersebut (kode 2,5,9,11,15,16,17), selanjutnya menggunakan -

(C) Poltekkes Kemenkes Jakarta I

J1. Wijaya Kusuma No. 47-48 Cilandak Jakarta Selatan, Indonesia email: jurnalquality@poltekkesjakarta1.ac.id
Tabel 2. Jumlah Sampel, dan Item Penilaian Kuesioner Pada Variabel yang Digunakan di Artikel Penelitian Partisipasi Masyarakat

\begin{tabular}{|c|c|c|c|c|c|c|}
\hline \multirow{2}{*}{$\begin{array}{l}\text { No } \\
\text { (ko } \\
\text { de) }\end{array}$} & \multirow[b]{2}{*}{$\begin{array}{l}\text { Penelitian } \\
\text { (artikel) }\end{array}$} & \multirow[b]{2}{*}{$\begin{array}{c}\text { banyak } \\
\text { sampel } \\
\text { artikel }\end{array}$} & \multicolumn{4}{|c|}{ Item Kuesioner pada Variabel } \\
\hline & & & $\begin{array}{c}\text { Sosiode } \\
\text { mografi } \\
\text { (item) }\end{array}$ & $\begin{array}{c}\text { Knowle } \\
\text { dge } \\
\text { (item) }\end{array}$ & $\begin{array}{c}\text { Attitu } \\
\text { de } \\
\text { (item) }\end{array}$ & $\begin{array}{l}\text { Practi } \\
\text { ce } \\
\text { (item) }\end{array}$ \\
\hline 1 & $\begin{array}{l}\text { (Vannavong, } \\
\text { Seidu, } \\
\text { Stenström, } \\
\text { Dada, \& } \\
\text { Overgaard, } \\
\text { 2017) }\end{array}$ & 487 & 6 & NA & NA & 6 \\
\hline 2 & $\begin{array}{l}\text { (Rakhmani, } \\
\text { Limpanont, } \\
\text { Kaewkungw } \\
\text { al, \& } \\
\text { Okanurak, } \\
\text { 2018) }\end{array}$ & 220 & 7 & 3 & 3 & 5 \\
\hline 3 & $\begin{array}{l}\text { (Nazareth et } \\
\text { al., 2014) }\end{array}$ & 1182 & 6 & 5 & 4 & NA \\
\hline 4 & $\begin{array}{l}\text { (Salawati, } \\
\text { 2018) }\end{array}$ & 100 & 4 & NA & NA & 3 \\
\hline 5 & $\begin{array}{l}\text { (Kumaran et } \\
\text { al., 2018) }\end{array}$ & 600 & 4 & 6 & 4 & 6 \\
\hline 6 & $\begin{array}{l}\text { (Patidar, } \\
\text { 2019) }\end{array}$ & 100 & 5 & 5 & NA & NA \\
\hline 7 & $\begin{array}{l}\text { (Fauziah, } \\
\text { Rahayu, \& } \\
\text { Thohari, } \\
\text { 2019) }\end{array}$ & 40 & NA & 3 & 3 & 3 \\
\hline 8 & $\begin{array}{l}\text { (Hastuti, } \\
\text { Dharmawan, } \\
\text { \& Indarto, } \\
\text { 2017) }\end{array}$ & 120 & 5 & NA & NA & 7 \\
\hline 9 & $\begin{array}{l}\text { (Udayanga et } \\
\text { al., 2018) }\end{array}$ & 400 & 19 & 6 & 7 & 10 \\
\hline 10 & $\begin{array}{l}\text { (Nivedita, } \\
2016 \text { ) }\end{array}$ & 300 & $\mathrm{NA}$ & 9 & 2 & 2 \\
\hline 11 & $\begin{array}{l}\text { (Diaz- } \\
\text { Quijano et } \\
\text { al., 2018) }\end{array}$ & 1057 & 2 & 17 & 11 & 3 \\
\hline 12 & $\begin{array}{l}\text { (Leslie et al., } \\
\text { 2017) }\end{array}$ & 60 & NA & 7 & 7 & NA \\
\hline 13 & $\begin{array}{l}\text { (Siddiqui, } \\
\text { Ghazal, Bibi, } \\
\text { Ahmed, \& } \\
\text { Sajjad, 2016) }\end{array}$ & 608 & 2 & 14 & 6 & NA \\
\hline 14 & $\begin{array}{l}\text { (Elsinga et } \\
\text { al., 2017) }\end{array}$ & 339 & 6 & NA & 6 & 6 \\
\hline 15 & $\begin{array}{l}\text { (Suwanbamr } \\
\text { ung, } \\
\text { Thoutong, } \\
\text { Eksirinimit, } \\
\text { Tongjan, \& }\end{array}$ & 503 & 5 & 14 & 16 & 2 \\
\hline
\end{tabular}

ISSN 2655-2434

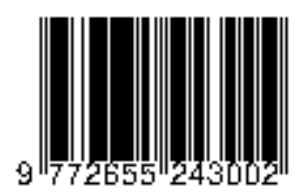




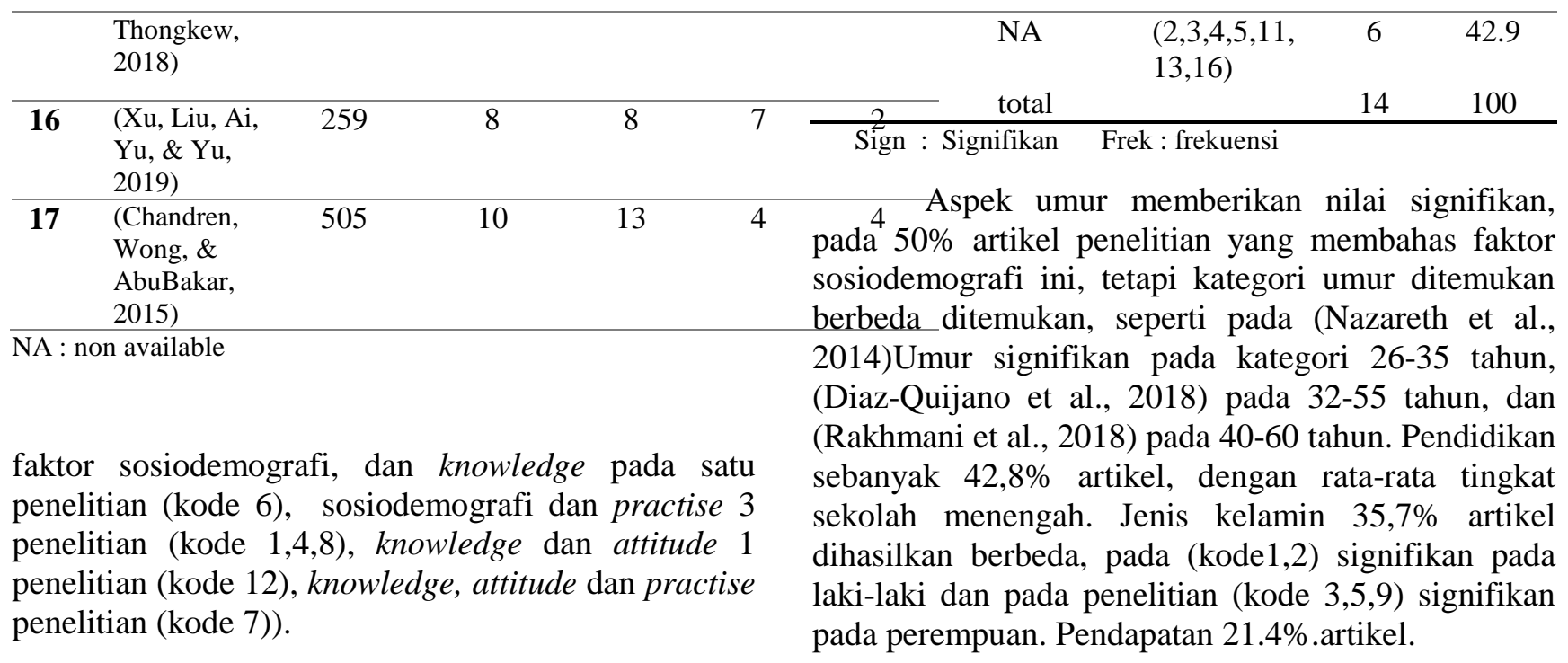

\section{Faktor Sosiodemografi}

Tabel 3 memperlihatkan beberapa aspek sosiodemografi yang diteliti pada partisipasi masyarakat. Banyak aspek dapat masuk dalam faktor ini, tetapi hanya 4 aspek yang paling banyak diteliti dihampir semua penelitian yaitu umur, jenis kelamin, pendidikan dan pendapatan.

Tabel 3. Faktor sosio demografi dalam penelitian partisipasi masyarakat pada pencegahan DBD

\begin{tabular}{|c|c|c|c|c|}
\hline \multirow[t]{2}{*}{ Faktor } & \multicolumn{4}{|c|}{ Hasil penelitian } \\
\hline & kategori & Kode & Frek. & $\begin{array}{c}\% \\
\text { artikel }\end{array}$ \\
\hline \multirow[t]{4}{*}{ Umur } & Signifikan & $\begin{array}{l}(1,2,3,5,9,1 \\
1,13)\end{array}$ & 7 & 50 \\
\hline & Tdk sign. & $(8,14,16,17$ & 4 & 28.6 \\
\hline & NA & ) & 3 & 21.4 \\
\hline & total & $(4,6,15)$ & 14 & 100 \\
\hline Jenis & Signifikan & $(1,2,3,5,9)$ & 5 & 35.7 \\
\hline \multirow[t]{2}{*}{ Kelamin } & Tdk sign. & $\begin{array}{l}(8,11,14,15 \\
, 16,17)\end{array}$ & 6 & 42.9 \\
\hline & $\begin{array}{l}\text { NA } \\
\text { total }\end{array}$ & $(4,6,13)$ & $\begin{array}{c}3 \\
14\end{array}$ & $\begin{array}{c}21.4 \\
100\end{array}$ \\
\hline \multirow[t]{4}{*}{ Pendidikan } & Signifikan & $\begin{array}{l}(1,3,6,11,1 \\
3,16)\end{array}$ & 6 & 42.8 \\
\hline & Tdk sign. & $(8,14,15,17$ & 4 & 28.6 \\
\hline & NA & ) & 4 & 28.6 \\
\hline & total & $(2,4,5,9)$ & 14 & 100 \\
\hline \multirow[t]{2}{*}{ Pendapata } & Signifikan & $(1,9,16)$ & 3 & 21.4 \\
\hline & Tdk sign. & $(6,8,14,15,17$ & 5 & 35.7 \\
\hline
\end{tabular}

(C) Poltekkes Kemenkes Jakarta I

Jl. Wijaya Kusuma No. 47-48 Cilandak Jakarta Selatan, Indonesia email: jurnalquality@poltekkesjakarta1.ac.id

\section{Faktor Knowledge, Attitude and Practice}

Pola pertanyaan kuesioner KAP pada pencegahan DBD biasanya, dikategorikan dalam 4 poin utama yaitu pengenalan penyakit, transmisi dan perkembangbiakan vektor serta cara pencegahan penyakit. Tabel-tabel adalah beberapa hasil penilaian artikel berdasarkan poin utama pada kuesioner KAP pencegahan DBD.

Tabel 4. Faktor knowledge upaya pencegahan penyakit DBD pada penelitian partisipasi masyarakat

\begin{tabular}{lllcc}
\hline \multicolumn{1}{c}{ Faktor } & \multicolumn{4}{c}{ Hasil penelitian } \\
\cline { 2 - 5 } & kategori & \multicolumn{1}{c}{ kode } & Frek & $\begin{array}{c}\% \\
\text { artikel }\end{array}$ \\
\cline { 2 - 5 } Sumber & Signifikan & $(10,11,12,13)$ & 4 & 30.8 \\
Informasi & Tdk sign. & $(2)$ & 1 & 7.7 \\
& NA & $(3,5,6,7,9,15$, & 8 & 61.5 \\
& & $16,17)$ & & \\
& total & & 13 & 100 \\
\hline Pengenalan & Signifikan & $(9,10,11,12$, & 6 & 46.2 \\
penyakit & & $13,15)$ & & \\
& Tdk sign. & $(5,6,17)$ & 3 & 23.1 \\
& NA & $(2,3,7,16)$ & 4 & 30.8 \\
& total & & 13 & 100 \\
\hline Cara & Signifikan & $(3,9,10,11,12)$ & 5 & 38.5 \\
transmisi & Tdk sign. & $(5,15,16,17)$ & 4 & 30.8 \\
vektor & NA & $(2,6,7,13)$ & 4 & 30.8 \\
& total & & 13 & 100 \\
\hline Perkembang & Signifikan & $(3,9,10,11,12)$ & 5 & 38.5 \\
biakan & Tdk sign. & $(5,15,16,17)$ & 4 & 30.8 \\
\hline
\end{tabular}

ISSN 2655-2434

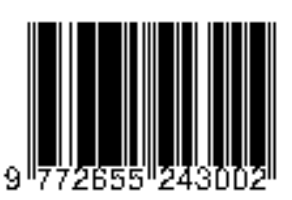




\begin{tabular}{|c|c|c|c|c|c|c|c|c|}
\hline Vector & $\begin{array}{l}\mathrm{NA} \\
\text { total }\end{array}$ & $(2,6,7,13)$ & $\begin{array}{c}4 \\
13\end{array}$ & $\begin{array}{l}\text { 30 Breeding site } \\
\text { 10Manajemen }\end{array}$ & Signifikan & $\begin{array}{l}(2,7,9,13 \\
15,16,17)\end{array}$ & 8 & 61.5 \\
\hline \multirow{4}{*}{$\begin{array}{l}\text { Cara } \\
\text { pencegahan } \\
\text { vektor }\end{array}$} & Signifikan & $(10,16,17)$ & 3 & 23 wadah air & Tdk sign. & $(3,12)$ & 2 & 15.4 \\
\hline & Tdk sign. & $(5,9,7,11,15)$ & 5 & 38.5 & & $\cdots$ & 3 & 23.1 \\
\hline & NA & $(2,3,6,12,13)$ & 5 & 38.5 & & & 13 & 100 \\
\hline & total & & 13 & 100paya & Signifikan & $(2,6,7,9,10$ & 9 & 69,2 \\
\hline \multirow{6}{*}{$\begin{array}{l}\text { Pengetahuan } \\
\text { secara } \\
\text { umum }\end{array}$} & Signifikan & $(2,6,9)$ & 3 & 23 pengendalian & & $13,14,15,17)$ & & \\
\hline & Tdk sign. & $(7,16,17)$ & 3 & 23.vektor & Tdk sign. & $(3,12)$ & 2 & 15.4 \\
\hline & NA & $(3,5,10,11,12$, & 7 & 58.8 & $\begin{array}{l}\text { NA } \\
\text { total }\end{array}$ & $\cdots$ & 2 & 15.4 \\
\hline & & $13,15)$ & & & & & 13 & 100 \\
\hline & total & & 13 & Rata-1 & ata peneliti & n signifikan & & 51,3 \\
\hline & ta-rata & fikan & & 33,4 & & & & \\
\hline
\end{tabular}

Sig : signifikan Frek : Frekuenai

Tabel 4 menunjukkan distribusi aspek pada faktor knowledge (pengetahuan) pencegahan DBD pada penelitian partisipasi masyarakat yang ditinjau. pada tabel menggambarkan perbedaan pengukuran aspek, sehingga tidak semua penelitian melakukan penilaian 4 poin utama pencegahan DBD. Aspek pengenalan penyakit, diketemukan signifikan pada $46,2 \%$ artikel, cara transmisi vektor $38,5 \%$ artikel, perkembangbiakan vektor $38,5 \%$ artikel, sumber informasi $30,8 \%$ artikel dan cara pencegahan vektor pada $23,1 \%$ artikel. Beberapa penelitian memberikan nilai signifikan dalam bentuk komposit, sehingga penulis mengkategorikan sebagai aspek pengetahuan pencegahan DBD secara umum, dan terdapat 23,1\% artikel. Rata-rata artikel penelitian signifikan pada faktor ini sebesar 33,4\% artikel.

Tabel 5 menunjukan distribusi tinjauan faktor attitude pencegahan DBD dalam penelitian partisipasi masyarakat. Aspek upaya pengendalian vektor memberikan persentase tertinggi yaitu 69,2\% artikel, aspek sikap terhadap tempat perindukan nyamuk/ bredding site signifikan pada $61.5 \%$ artikel, dan transmisi vektor $23,1 \%$ artikel. Rata-rata artikel yang mempunyai nilai signifikan pada faktor attitude berdasarkan aspek yang dinilai sebesar 51,3\% artikel.

Tabel 5. Faktor Attitude upaya pencegahan DBD pada penelitian partisipasi masyarakat

\begin{tabular}{lllcc}
\hline \multicolumn{1}{c}{ Faktor } & \multicolumn{4}{c}{ Hasil penelitian } \\
& kategori & \multicolumn{1}{c}{ kode } & Frek. & $\%$ \\
& & & & \\
\hline Transmisi & Signifikan & $(9,10,11)$ & 3 & 23.1 \\
vektor & Tdk sign. & $(12,17)$ & 1 & 7.7 \\
& NA & $(2,3,5,7,13$, & 8 & 69,2 \\
& total & $14,15,16)$ & & \\
& & & 13 & 100 \\
\hline
\end{tabular}

(C) Poltekkes Kemenkes Jakarta I

Jl. Wijaya Kusuma No. 47-48 Cilandak Jakarta Selatan, Indonesia email: jurnalquality@poltekkesjakarta1.ac.id
Aspek attitude pada hanya memberikan satu artikel signifikan, dari 3 artikel yang membahas,sehingga dikeluarkan dari perhitungan rata-rata.

Tabel 6 menunjukan distribusi tinjauan faktor practise (tindakan) pencegahan DBD pada penelitian partisipasi masyarakat. aspek yang paling banyak diteliti dan juga terbanyak memberikan nilai signifikan adalah manajemen wadah air yang signifikan pada $53,8 \%$ artikel.

Tabel 6. Faktor practice upaya pencegahan DBD pada penelitian partisipasi masyarakat

\begin{tabular}{|c|c|c|c|c|}
\hline \multirow[t]{2}{*}{ Faktor } & \multicolumn{4}{|c|}{ Hasil penelitian } \\
\hline & Kategori & kode & Total & $\begin{array}{c}\% \\
\text { artikel }\end{array}$ \\
\hline \multirow{4}{*}{$\begin{array}{l}\text { pencarian } \\
\text { pengobatan }\end{array}$} & Signifikan & $(9,10)$ & 2 & 15.4 \\
\hline & Tdk sign. & $(5,11)$ & 2 & 15.4 \\
\hline & NA & $1,2,4,7,8,14,15,16,17)$ & 9 & 69.2 \\
\hline & Total & & 13 & 100 \\
\hline \multirow{4}{*}{$\begin{array}{l}\text { Penurunan } \\
\text { kejadian DBD }\end{array}$} & Signifikan & $(7,8,9,11)$ & 4 & 30,8 \\
\hline & Tdk sign. & $(5,17)$ & 2 & 15,4 \\
\hline & NA & $(1,2,4,10,14,15,16)$ & 7 & 53,8 \\
\hline & Total & & 13 & 100 \\
\hline \multirow{4}{*}{$\begin{array}{l}\text { Manajemen } \\
\text { wadah air }\end{array}$} & Signifikan & $(5,7,9,10,14,15)$, & 6 & 46.1 \\
\hline & Tdk sign. & $(1,11,16,17)$ & 3 & 23.1 \\
\hline & NA & $(2,4,8)$ & 4 & 30.8 \\
\hline & Total & & 13 & 100 \\
\hline \multirow{4}{*}{$\begin{array}{l}\text { Pengendalian } \\
\text { vector }\end{array}$} & Signifikan & $(2,4,7,9,16,17)$ & 6 & 38,5 \\
\hline & Tdk sign. & $(1,11)$ & 2 & 15.4 \\
\hline & NA & $(5,8,10,14,15)$ & 5 & 46.1 \\
\hline & Total & & 13 & 100 \\
\hline Indeks & Signifikan & $(4,7,8,9,15,16)$ & 6 & 38.5 \\
\hline \multirow{3}{*}{ entomologis } & Tdk sign. & (14) & 1 & 7.7 \\
\hline & NA & $(1,2,5,10,11,17)$ & 6 & 53.8 \\
\hline & Total & & 13 & 100 \\
\hline \multicolumn{4}{|c|}{ Rata-rata penelitian signifikan } & 33,9 \\
\hline
\end{tabular}

ISSN 2655-2434 
Tindakan manajemen wadah air dilakukan berupa kegiatan membersihkan dan menutup wadahwadah air. Tindakan pengendalian vektor lain berupa mengubur barang bekas, sanitasi lingkungan, pemberian larvasida, pelaksanaan foging, dikelompokan kedalam tindakan pengendalian vektor dan signifikan pada $38,5 \%$ artikel. Tindakan pengukuran keberadaan jentik dengan menggunakan indeks entomologis signifikan sebanyak $38,5 \%$ artikel dan hasil tindakan dengan melakukan pengukuran kejadian DBD signifikan pada $30,8 \%$ artikel. Pengukuran tindakan yang paling sedikit dilakukan, adalah tindakan pencarian pengobatan yang signifikan pada $15,4 \%$ artikel. Jumlah rata-rata penelitian yang signifikan terhadap faktor practise adalah sebesar $33,86 \%$ artikel.

Tabel 7. Temuan penelitian partisipasi masyarakat

\begin{tabular}{|c|c|c|}
\hline $\begin{array}{l}\text { Penelitian } \\
\text { (artikel) }\end{array}$ & temuan & kesimpulan \\
\hline $\begin{array}{l}\text { (Vannavong et } \\
\text { al., 2017) }\end{array}$ & $\begin{array}{l}\text { frekuensi } \\
\text { membersihkan } \\
\text { wadah air } \\
\text { merupakan faktor } \\
\text { yang signifikan }\end{array}$ & $\begin{array}{l}\text { membersihkan } \\
\text { wadah air } \\
\text { signifikan } \\
\text { terhadap } \\
\text { berkembang } \\
\text { biaknya jentik } \\
\text { nyamuk. }\end{array}$ \\
\hline $\begin{array}{l}\text { (Rakhmani et } \\
\text { al., 2018) }\end{array}$ & $\begin{array}{l}\text { Faktor gender } \\
\text { Wanita, berusia } \\
40-60 \text { dan jumlah } \\
\text { anggota keluarga } \\
>3 \text { memberikan } \\
\text { hasil signifikan } \\
\text { terhadap sikap } \\
\text { pembersihan } \\
\text { wadah air }\end{array}$ & $\begin{array}{l}\text { Tingkat } \\
\text { pengetahuan } \\
\text { tidak berpengaruh } \\
\text { terhadap sikap }\end{array}$ \\
\hline $\begin{array}{l}\text { (Nazareth et } \\
\text { al., 2014) }\end{array}$ & $\begin{array}{l}\text { Ada mitos tentang } \\
\text { penyakit DBD } \\
\text { pada populasi ini }\end{array}$ & $\begin{array}{l}\text { Untuk mengubah } \\
\text { persepsi terhadap } \\
\text { mitos, dengan } \\
\text { meningkatkan } \\
\text { pengetahuan }\end{array}$ \\
\hline $\begin{array}{l}\text { (Salawati, } \\
\text { 2018) }\end{array}$ & $\begin{array}{l}\text { membandingkan } \\
\text { perilaku } \\
\text { pemberantasan } \\
\text { sarang nyamuk } \\
\text { (PSN) dengan } \\
\text { keberadaan jentik } \\
\text { nyamuk, makin } \\
\text { buruk PSN, makin }\end{array}$ & $\begin{array}{l}\text { Peningkatan } \\
\text { pengetahuan } \\
\text { dengan } \\
\text { penyuluhan untuk } \\
\text { meningkatkan } \\
\text { kesadaran } \\
\text { terhadap perilaku } \\
\text { PSN }\end{array}$ \\
\hline
\end{tabular}

(C) Poltekkes Kemenkes Jakarta I

Jl. Wijaya Kusuma No. 47-48 Cilandak Jakarta Selatan, Indonesia email: jurnalquality@ poltekkesjakarta1.ac.id

\begin{tabular}{|c|c|c|}
\hline & $\begin{array}{l}\text { banyak jentik } \\
\text { nyamuk }\end{array}$ & \\
\hline $\begin{array}{l}\text { (Kumaran et } \\
\text { al., 2018) }\end{array}$ & $\begin{array}{l}\text { Pengetahuan } \\
\text { tentang penyakit } \\
\text { DBD (risiko } \\
\text { penyakit, } \\
\text { transmisi, tempat } \\
\text { perindukan } \\
\text { nyamuk, tidak } \\
\text { signifikan dengan } \\
\text { perilaku } \\
\text { pencegahan vektor. }\end{array}$ & $\begin{array}{l}\text { Tingkat } \\
\text { Pengetahuan } \\
\text { terhadap DBD } \\
\text { tinggi tetapi } \\
\text { perilaku kurang } \\
\text { mendukung } \\
\text { upaya } \\
\text { pencegahan } \\
\text { DBD }\end{array}$ \\
\hline (Patidar, 2019) & $\begin{array}{l}\text { Tingkat } \\
\text { pengetahuan } \\
\text { signifikan hanya } \\
\text { terhadap variabel } \\
\text { demografi seperti } \\
\text { status pendidikan, } \\
\text { usia }\end{array}$ & $\begin{array}{l}\text { Penelitian hanya } \\
\text { menilai } \\
\text { pengetahuan } \\
\text { tentang penyakit } \\
\text { DBD, tidak } \\
\text { menilai persepsi } \\
\text { dan perilaku }\end{array}$ \\
\hline $\begin{array}{l}\text { (Fauziah et al., } \\
\text { 2019) }\end{array}$ & $\begin{array}{ll} & \text { Penelitian } \\
\text { tentang } \\
\text { perilaku 3M. } \\
\text { Melakukan } \\
\text { penilaian KAP } \\
\text { dan indeks } \\
\text { entomologi } \\
\text { serta angka } \\
\text { kejadian DBD }\end{array}$ & $\begin{array}{l}\text { Variabel yang } \\
\text { tidak signifikan } \\
\text { adalah } \\
\text { pengetahuan yang } \\
\text { dihubungkan } \\
\text { dengan perilaku } \\
\text { 3M }\end{array}$ \\
\hline $\begin{array}{l}\text { (Hastuti et al., } \\
\text { 2017) }\end{array}$ & 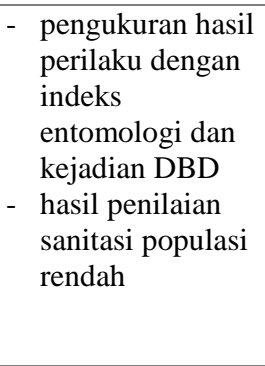 & $\begin{array}{l}\text { perilaku sanitasi } \\
\text { yang rendah } \\
\text { meningkatkan } \\
\text { kejadian DBD, } \\
\text { dan upaya } \\
\text { pencegahannya } \\
\text { melalui kegiatan } \\
\text { PSN } \\
\text { (pemberantasan } \\
\text { sarang nyamuk) }\end{array}$ \\
\hline $\begin{array}{l}\text { (Udayanga et } \\
\text { al., 2018) }\end{array}$ & $\begin{array}{l}\text { Faktor } \\
\text { pengetahuan, sikap } \\
\text { dan perilaku } \\
\text { memberikan hasil } \\
\text { signifikan pada } \\
\text { beberapa poin, } \\
\text { tetapi tidak } \\
\text { signifikan di } \\
\text { beberapa poin } \\
\text { lainnya }\end{array}$ & $\begin{array}{l}\text { Agar kegiatan } \\
\text { dapat } \\
\text { berkesinambunga } \\
\text { n dibutuhkan } \\
\text { peningkatan } \\
\text { motivasi dan } \\
\text { komunikasi, } \\
\text { integrasi }\end{array}$ \\
\hline $\begin{array}{l}\text { (Nivedita, } \\
\text { 2016) }\end{array}$ & $\begin{array}{l}\text { Pengetahuan, sikap } \\
\text { dan perilaku } \\
\text { tentang penyakit } \\
\text { DBD, meningkat } \\
\text { setelah diberikan } \\
\text { KIE }\end{array}$ & $\begin{array}{l}\text { KIE meningkan } \\
\text { pengetahuan, } \\
\text { kesadaran dan } \\
\text { perilaku dalam } \\
\text { pencegahan } \\
\text { DBD }\end{array}$ \\
\hline \multirow[t]{2}{*}{$\begin{array}{l}\text { (Diaz-Quijano } \\
\text { et al., 2018) }\end{array}$} & $\begin{array}{l}\text { Sikap pada aspek } \\
\text { transmisi vektor }\end{array}$ & $\begin{array}{l}\text { tingkat } \\
\text { pendidikan yang }\end{array}$ \\
\hline & \multicolumn{2}{|r|}{ ISSN 2655-2434 } \\
\hline
\end{tabular}




\begin{tabular}{|c|c|c|}
\hline & $\begin{array}{l}\text { dan breeding site } \\
\text { signifikan pada } \\
\text { penelitian ini, } \\
\text { tetapi manajemen } \\
\text { dan pengendalian } \\
\text { vektor tidak } \\
\text { signifikan }\end{array}$ & $\begin{array}{l}\text { rendah sangat } \\
\text { rentan dalam } \\
\text { melakukan } \\
\text { intervensi } \\
\text { program }\end{array}$ \\
\hline $\begin{array}{l}\text { (Leslie et al., } \\
\text { 2017) }\end{array}$ & $\begin{array}{l}\text { Populasi adalah } \\
\text { populasi } \\
\text { berpendidikan, } \\
\text { dengan asal } \\
\text { informasi } \\
\text { terbanyak dari } \\
\text { internet, tetapi } \\
\text { hasil penelitian } \\
\text { tidak sebanding } \\
\text { dengan sikap } \\
\text { bahwa penyakit } \\
\text { ditularkan dari } \\
\text { nyamuk }\end{array}$ & $\begin{array}{l}\text { Karena penyakit } \\
\text { ini dianggap } \\
\text { sebagai neglected } \\
\text { disease membuat } \\
\text { masyarakat tidak } \\
\text { berperilaku yang } \\
\text { sesuai, sehingga } \\
\text { dibutuhkan } \\
\text { komunikasi dan } \\
\text { motivasi } \\
\text { kesehatan untuk } \\
\text { mengubah } \\
\text { persepsi }\end{array}$ \\
\hline $\begin{array}{l}\text { (Siddiqui et } \\
\text { al., 2016) }\end{array}$ & $\begin{array}{l}\text { - Pengetahuan yang } \\
\text { dimiliki publik } \\
\text { tentang penyakit } \\
\text { DBD rendah, } \\
\text { asal informasi } \\
\text { terbanyak dari } \\
\text { televisi } \\
\text { - Sikap dan efikasi } \\
\text { diri terhadap } \\
\text { penyakit ini } \\
\text { rendah }\end{array}$ & $\begin{array}{l}\text { Strategi } \\
\text { pengendalian } \\
\text { dengue harus } \\
\text { fokus pada } \\
\text { peningkatan } \\
\text { kesadaran tentang } \\
\text { risiko penyakit } \\
\text { yang dapat } \\
\text { dilakukan dengan } \\
\text { media televisi } \\
\text { sebagai sumber } \\
\text { yang sering } \\
\text { diakses } \\
\text { masyarakat. }\end{array}$ \\
\hline $\begin{array}{l}\text { (Elsinga et al., } \\
2017)\end{array}$ & $\begin{array}{l}\text { - Melakukan } \\
\text { kegiatan } \\
\text { peningkatan } \\
\text { kapasitas dengan } \\
\text { istilah mosquito } \\
\text { breeding site } \\
\text { control (MBSC) } \\
\text { - Adanya populasi } \\
\text { kunci yang } \\
\text { proaktif } \\
\text { memotivasi } \\
\text { masyarakat dalam } \\
\text { MBSC }\end{array}$ & $\begin{array}{l}\text { Populasi kunci } \\
\text { yang proaktif } \\
\text { merupakan kunci } \\
\text { masyarakat } \\
\text { berpengetahuan } \\
\text { dan berperilaku } \\
\text { yang sesuai }\end{array}$ \\
\hline $\begin{array}{l}\text { (Suwanbamrun } \\
\text { g et al., 2018) }\end{array}$ & $\begin{array}{l}\text { - Pengembangan } \\
\text { model } \\
\text { pengawasan } \\
\text { jentik dengan } \\
\text { menggunakan } \\
\text { pendekatan } \\
\text { Community } \\
\text { participation } \\
\text { action research } \\
\text { (CPAR) di kota } \\
\text { Lansaka, } \\
\text { Thailand }\end{array}$ & $\begin{array}{l}\text { Penembangan } \\
\text { model dengan } \\
\text { melakukan } \\
\text { kemitraan untuk } \\
\text { meningkatkan } \\
\text { partisipasi } \\
\text { masyarakat } \\
\text { memberikan hasil } \\
\text { yang baik dalam } \\
\text { peningkatan } \\
\text { pengetahuan } \\
\text { sikap dan }\end{array}$ \\
\hline
\end{tabular}

(C) Poltekkes Kemenkes Jakarta I

Jl. Wijaya Kusuma No. 47-48 Cilandak Jakarta Selatan, Indonesia email: jurnalquality@poltekkesjakarta1.ac.id

\begin{tabular}{|c|c|c|}
\hline & 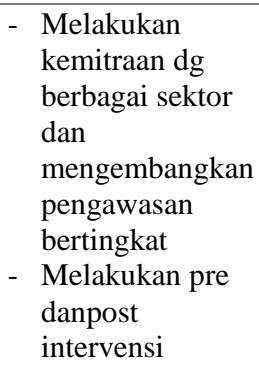 & $\begin{array}{l}\text { perilaku terhadap } \\
\text { pencegahan } \\
\text { DBD }\end{array}$ \\
\hline $\begin{array}{l}\text { (Xu et al., } \\
\text { 2019) }\end{array}$ & $\begin{array}{l}\text { Penelitian } \\
\text { dilakukan pada } \\
\text { suku } \\
\text { Shan/pedalaman } \\
\text { yang memiliki } \\
\text { keyakinan bahwa } \\
\text { penyakit } \\
\text { disebabkan oleh } \\
\text { lingkungan } \\
\text { sehingga perilaku } \\
\text { membersihkan } \\
\text { rumah secara } \\
\text { teratur selalu } \\
\text { dilakukan tetapi } \\
\text { tingkat kesadaran } \\
\text { terhadap penyakit } \\
\text { DBD rendah. }\end{array}$ & $\begin{array}{l}\text { Perilaku } \\
\text { membersihkan } \\
\text { rumah secara } \\
\text { teratur } \\
\text { merupakan salah } \\
\text { satu perilaku } \\
\text { mendukung } \\
\text { pencegahan } \\
\text { DBD, tetapi } \\
\text { harus dibantu } \\
\text { dengan } \\
\text { pengetahuan } \\
\text { lainnya agar tepat } \\
\text { tindakan; } \\
\text { sehingga } \\
\text { memerlukan } \\
\text { suatu strategi } \\
\text { untuk } \\
\text { meningkatkan } \\
\text { kesadaran }\end{array}$ \\
\hline $\begin{array}{l}\text { (Chandren et } \\
\text { al., 2015) }\end{array}$ & $\begin{array}{l}\text { Penelitan } \\
\text { dilakukan pada } \\
\text { suku } \\
\text { pedalaman/orang } \\
\text { asli dengan } \\
\text { sebagian besar } \\
\text { pendidikan dan } \\
\text { sosioekonomi } \\
\text { rendah tetapi } \\
\text { memilki kebiasaan } \\
\text { menutup wadah air }\end{array}$ & $\begin{array}{l}\text { Perilaku } \\
\text { kesehatan sudah } \\
\text { dimiliki tetapi } \\
\text { perlu suatu } \\
\text { strategi agar tepat } \\
\text { sasaran }\end{array}$ \\
\hline
\end{tabular}

\section{Pembahasan}

Berdasarkan hasil screening artikel dengan menggunakan protokol PRISMA, dari 17 penelitian kuantitatif. Tabel 1 menjelaskan persebaran artikel berdasarkan faktor yang digunakan, sedang tabel 2 penjabaran penjabaran item kuesioner dan persebaran penggunaan faktor pada artikel. Tabel 3-6 merupakan penjabaran aspek pada masing-masing faktor, dan tabel 7 temuan pada tinjauan sistematik.

Penelitian ini memiliki banyak keterbatasan antara lain karena skala yang diambil tidak membatasi negara atau benua, pembatasan jumlah sampel, ISSN 2655-2434

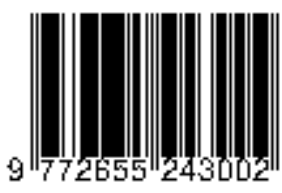


sehingga hasil memberikan heterogenitas yang terlalu tinggi. Selain itu penulis tidak membatasi desain studi kuantitatif dengan maksud mendapatkan lebih banyak informasi yang dapat digali, sehingga terdapat desain studi crosssectional, casecontrol, kohort, dan survey. Presentasi hasil yang disajikan pada tabel 3-6 menggambarkan persentase jumlah artikel dari aspek yang signifikan pada masing-masing penelitian. Perhitungan dilakukan dengan membagi jumlah aspek yang signifikan pada artikel dibagi keseluruh penelitian yang menggunakan variabel yang dinilai, sehingga dapat terjadi bias pada perhitungan dengan adanya komponen non available. Nilai rata-rata sebagai presentasi faktor signifikan diambil dari persentase tiap aspek signifikan dibagi jumlah seluruh aspek.

Pada tabel 2 menggambarkan persebaran sampel dan faktor-faktor yang digunakan pada penelitian partisipasi masyarakat. artikel-artikel menghubungkan berbagai faktor yang berbeda-beda, penggunaan faktor sosiodemografi, dan knowledge pada (patidar 2019) menghubungkan aspek sosiodemografi dengan pengetahuan pencegahan DBD. Aspek sosiodemografi yang dihubungkan dengan faktor practise manajemen wadah air dengan pengukuran indeks entomologis pada (Vannavong et al., 2017) (salawati 2018) dan (Hastuti, Dharmawan, and Indarto 2017) menghubungkan dengan kegiatan pengendalian vektor. knowledge dan attitude pada (leslie et al 2018) menghubungkan tingkat pengetahuan dengan sikap terhadap penyakit DBD bahwa pengetahuan yang tinggi tidak secara signifikan memberikan sikap yang baik terhadap penyakit ini sehingga diperlukan motivasi agar masyarakat kedepannya dapat berpartisipasi untuk melakukan pencegahan penyakit ini, dan sejalan dengan penelitian (hastuti 2017). Penelitian (Hastuti 2017) juga memberikan hasil sanitasi yang buruk meningkatkan kejadian DBD. dengan faktor knowledge, attitude dan practise pada (Fauziah, Rahayu and Thohari 2019) adalah penilaian kegiatan $3 \mathrm{M}$ yang diukur dari pengetahuan, sikap dan perilaku, tanpa menjelaskan faktor sosiodemografi sampel. Penelitian dengan keempat faktor memberikan gambaran lebih komprehensif, dan dapat digunakan untuk penilaian awal suatu intervensi yang mendorong partisipasi masyarakat seperti pada penelitian (Xu et al. 2019) dan (Chandren et al., 2015) maupun pembentukan proyek pemodelan seperti pada (C) Poltekkes Kemenkes Jakarta I

Jl. Wijaya Kusuma No. 47-48 Cilandak Jakarta Selatan, Indonesia email: jurnalquality@poltekkesjakarta1.ac.id penelitian (Suwanbamrung et al., 2018) dengan Lansaka Modelnya.

Variabel sosiodemografi pada penelitian (tabel 3) tidak selalu dilakukan pengukuran hubungan, melainkan dapat digunakan hanya sebagai karekteristik responden seperti pada penelitian (salawati 2018) dan (kumaran et.al 2018). Sehingga beberapa penelitian yang tidak menguraikan dan mencantumkan faktor ini. Penelitian yang mencantumkan faktor ini tetapi tidak melakukan analisa hubungan ditemukan pada (Nivedita 2016) (Leslie et al., 2017), dimana sampel yang digunakan dianggap homogen.

Faktor sosiodemografi (tabel 3) pada aspek umur 50\% artikel atau sebanyak 7 artikel (kode $2,3,5,9,11,13)$, tetapi tidak memiliki nilai standar, karena umur pada (Nazareth et al., 2014), yang signifikan didapatkan umur 26-35 tahun; 32-55 tahun pada (Diaz-Quijano et al., 2018) 40-60 tahun pada (Rakhmani et al., 2018). Pada jenis kelamin signifikan pada perempuan di penelitian Vannavong et al. 2017) dan (Rakhmani et al., 2018) sedangkan di penelitian (Nazareth et al., 2014), (Fauziah et al., 2019) dan (Udayanga et al., 2018) signifikan pada laki-laki, adanya perbedaan umur dan jenis kelamin yang berbeda pada penelitian yang memberikan hasil signifikan kemungkinan disebabkan persebaran sampel yang kurang seimbang. Aspek status pendidikan signifikan pada 5 penelitian (kode $3,6,11,13,16)$ dengan rata-rata tingkat pendidikan adalah pada tingkat sekolah menengah di menurut (Vannavong et al., 2017) tingkat pendidikan berpengaruh terhadap perilaku membersihkan wadah air, sedangkan menurut (Diaz-Quijano et al., 2018) dan (Siddiqui et al., 2016) tingkat pendidikan yang rendah menyebabkan sangat rentan terhadap perilaku yang tidak sesuai dengan kesehatan dan dibutuhkan upaya peningkatan kesadaran dalam meningkatkan literasi kesehatan. Tingkat pendapatan yang rendah memberikan hubungan negatif terhadap partisipasi masyarakat ditemukan pada penelitian (Udayanga et al., 2018) dan (Xu et al. 2019).

Pengetahuan atau kognitif merupakan domain yang sangat penting untuk pembentukan tindakan seseorang (Blum,1908 dalam Notoatmojo 2014), sehingga dapat dikatakan bahwa pengetahuan tentang pencegahan terhadap penyakit DBD seharusnya merupakan faktor yang sangat berpengaruh pada

ISSN 2655-2434 
tindakan upaya tindakan pencegahan DBD. Pada Faktor knowledge (tabel 4) dari 13 artikel yang menggunakan faktor ini, hasil signifikan tertinggi didapatkan dari aspek pengenalan penyakit yaitu item pertanyaan tentang penyebab, gejala dan tanda-tanda bila seseorang terkena DBD yang signifikan pada 46,2 $\%$ item, dan nilai rata-rata pada faktor ini sebesar $33,4 \%$. komponen penelitian-penelitian di variabel knowledge upaya pencegahan penyakit DBD persentasenya masih rendah. Komponen paling tinggi terkait faktor pengetahuan pada aspek pengenalan penyakit, diikuti dengan aspek pengetahuan cara transmisi dan perkembangbiakan vektor, tetapi aspek cara pencegahan vektor hanya signifikan di 3 penelitian, sebagaimana penelitian (Rakhmani et al., 2018) (Kumaran et al., 2018) dan (Fauziah et al., 2019) mendapatkan informasi bahwa tingkat pengetahuan terhadap penyakit DBD dan pencegahannya yang tinggi belum berhubungan dengan sikap dan tindakan yang sesuai dengan kesehatan, sedangkan menurut (Nazareth et al., 2014) (Nivedita 2016) peningkatan pengetahuan dapat meningkatkan kesadaran, persepsi dan perilaku yang diharapkan kesehatan, bahkan (Elsinga et al., 2017) melakukan penelitian agar tercipta kondisi masyarakat yang berpengetahuan dan bersikap dalam mosquito breeding site control (MBSC) menggunakan populasi kunci yang pro aktif untuk memotivasi masyarakat dan (Suwanbamrung et al., 2018) menggunakan pendekatan Community participation action research (CPAR) dalam pengembangan model Lansakanya. Beberapa penelitian menunjukan masih banyak yang memberikan hasil yang tidak signifikan terhadap kesemua aspeknya. Hal ini memberikan gambaran perlunya upaya yang keras dalam memberikan informasi dan memotivasi masyarakat bila kita ingin melakukan kegiatan peningkatan pengetahuan terhadap pencegahan penyakit DBD. Informasi yang tepat sasaran menjadi salah satu senjata dalam promosi kesehatan, seharusnya pendidik kesehatan mengetahui media apa yang paling banyak digunakan populasi kunci, oleh karena itu aspek sumber informasi dapat digunakan untuk meningkatkan cakupan dalam promosi kesehatan. Namun berdasarkan hasil tinjuan hanya $30,8 \%$ penelitian yang menggunakan aspek ini.

Menurut (Notoatmodjo, 2014) sikap adalah respon tertutup seseorang terhadap stimulus atau objek tertentu, dengan melibatkan faktor pendapat dan emosi yang bersangkutan, atau kecenderungan untuk (C) Poltekkes Kemenkes Jakarta I

Jl. Wijaya Kusuma No. 47-48 Cilandak Jakarta Selatan, Indonesia email: jurnalquality@poltekkesjakarta1.ac.id bertindak atau berperilaku terhadap sesuatu sesuai keyakinannya. suatu sikap menjadi kekuatan yang nyata diperlukan factor pendukung antara lain fasilitas, dukungan dari pihak lain serta pengalaman, lingkungan dan motivasi (Azwar 1988). Pengukuran aspek-aspek pada faktor attitude upaya pencegahan DBD, ditemukan hasil signifikan terbanyak pada aspek upaya pengendalian vektor, dari 13 artikel penelitian, 9 artikel $(69,2 \%)$ nya signifikan pada aspek ini. Upaya pengendalian vektor yang dimaksud adalah berupa sikap terhadap pemberantasan sarang nyamuk seperti sikap terhadap upaya 3M (Fauziah, Rahayu, and Thohari 2019, sikap terhadap sanitasi lingkungan, (Salawati, 2018) (Udayanga et al., 2018) (Siddiqui et al. 2016) pemberian larvasida, pemberantasan nyamuk dewasa (Patidar, 2019). Sikap terhadap tempat perindukan nyamuk memberikan hasil yang signifikan pada hampir semua penelitian yang memberikan hasil signifikan pada aspek pengendalian vektor, kecuali pada penelitian (Nazareth et al., 2014) yang tidak memberikan hasil signifikan karena masih banyak mitos yang berkembang terkait penyakit ini dan pada (Leslie et al., 2017) responden merasa penyakit ini merupakan tanggung jawab pemerintah, sehingga sikap terhadap partisipasi masyarakatnya dirasakan kurang. Sikap terhadap transmisi vektor lebih rendah dibandingkan pengetahuan pada transmisi, padahal salah satu cara untuk mencegah kita tergigit nyamuk adalah dengan menghindari kontak pada masa vektor bertransmisi, biasanya karena rancu dengan transmisi pada nyamuk lain seperti pada penelitian (Leslie et al., 2017), Secara keseluruhan rata-rata faktor attitude memberikan nilai rata-rata 51,3 sedikit lebih tinggi dari pada nilai rata-rata knowledge dan practise.

Tabel 6 membahas faktor practise pencegahan DBD dalam penelitian partisipasi masyarakat. tindakan yang diharapkan adalah bentuk perilaku sehat. Menurut Becker,1979 dalam (Notoatmodjo, 2014) perilaku sehat adalah usaha untuk mempertahankan dan meningkatkan kesehatan. Perilaku manusia diketahui memainkan peran penting dalam kelanjutan eksistensi vektor dengue dan penularan virus (Higa, 2011), tetapi manajemen wadah air sebagai perilaku terhadap tempat perkembangbiakab nyamuk hanya memberikan hasil signifikan di 7 artikel dari $13(53,8 \%)$ penelitian pada faktor ini, demikian juga dengan tindakan pengendalian vektor hanya signifikan pada $38,5 \%$ ISSN 2655-2434

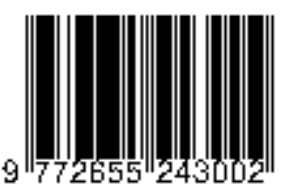


padahal upaya memberantas sarang tempat perkembangbiakan nyamuk dan mengendalikan vektor DBD merupakan upaya utama dalam IVM (integrated vector management) (WHO.int, 2012). Perilaku terhadap pencegahan demam bardarah dapat tidak berbanding dengan pendidikan dan pengetahuan masyarakat seperti pada (Salawati, 2018), (Kumaran et al., 2018), (Patidar, 2019), (Udayanga et al., 2018), (Suwanbamrung et al., 2018). sehingga perlunya meningkatkan motivasi dan komunikasi kesehatan. Pengukuran hasil tindakan di beberapa penelitian dengan menilai output yang diharapkan seperti penurunan kejadian penyakit DBD seperti penelitian dan penggunaan parameter entomologi (container index (CI), house index (HI) dan pupae index (PI)), (Salawati, 2018) (Elsinga et al., 2017) (Hastuti et al., 2017) maupun keduanya (7,8,9). (Hastuti et al., 2017) (Fauziah et al., 2019) (Udayanga et al., 2018).

Kajian dan kesimpulan dari artikel dapat ditemukan pada tabel 7. Penelitian-penelitian banyak membahas analisis faktor KAP dengan populasi wilayahnya sebagai asesment intervensi awal, seperti metode pendekatan pada masyarakat antara lain pada penelitian (Chandren et al., 2015) yang mengambil sampel orang asli suku pedalaman di Malaysia, (Xu et al .2019) mengambil suku Shan; intervensi program seperti (Fauziah et al., 2019), (Hastuti, Dharmawan, and Indarto 2017, mengetahui media sebagai saluran informasi seperti (Siddiqui et al., 2016), maupun evaluasi (Nazareth et al., 2014), Beberapa penelitian melakukan pengembangan model, seperti (Suwanbamrung et al., 2018) dengan pengembangan kemitraan multisektor diwilayah Lansaka, Myanmar, dengan nama Lansaka Model, (Elsinga et al., 2017) dengan peningkatan kapasitas dan pembentukan kelompok populasi kunci yang pro aktif dalam program mosquito breeding site control (MBSC). yang dapat dijadikan referensi dalam promosi kesehatan maupun upaya peningkatan partisipasi pada masyarakat.

\section{Kesimpulan dan Saran}

Kesadaran diri merupakan salah satu faktor yang mendorong partisipasi masyarakat yang dapat diukur dengan menggunakan penelitian KAP. Dalam upaya pencegahan penyakit DBD, biasanya aspek (C) Poltekkes Kemenkes Jakarta I

Jl. Wijaya Kusuma No. 47-48 Cilandak Jakarta Selatan, Indonesia email: jurnalquality@poltekkesjakarta1.ac.id yang dinilai meliputi pengenalan penyakitm transmisi vektor, tempat perindukan vektor dan cara pencegahannya, yang dapat diaplikasikan pada kuesioner. Hasil dari kajian artikel penelitian, ditemukan persentase artikel yang memberikan nilai signifikan pada faktor-faktor KAP rendah.

Perilaku kesehatan dalam pencegahan DBD merupakan upaya partisipasi masyarakat yang penting, tetapi beberapa penelitian tidak memberikan hubungan antara pengetahuan dengan sikap serta perilaku positif, sehingga peningkatan kesadaran, tentang risiko, motivasi dan komunikasi diperlukan sebagai upaya untuk mengubah perilaku. Hasil dari tindakan juga dapat memberikan output langsung yaitu penurunan angka kejadian DBD dan jumlah jentik nyamuk yang rendah yang diukur dengan indeks entomologi. Kajian ini juga memberikan temuan dari masing-masing artikel yang dapat dijadikan best prectise dan acuan pada penelitian lebih lanjut, karena beberapa penelitian menunjukan upaya pendekatan partisipasi masyarakat pada penelitian pencegahan DBD di awal, saat intervensi dan evaluasi, serta beberapa penelitan lainnya memberikan bentuk pengembangan model partisipasi masyarakat.Terakhir penulis harapkan berbagai keterbatasan penelitian diharapkan dapat dikurangi pada penelitian lebih lanjut.

\section{Singkatan}

Freq : frekuensi

NA : non available;

Sig: signikan;

$\%$ sig : persentase item yang signifikan dari jumlah artikel yang menggunakan variabel tersebut;

\section{Daftar Pustaka}

CDC. (2019). About Dengue What you need to know. Retrieved from web page website: https://www.cdc.gov/dengue/about/index.html

Chandren, J. R., Wong, L. P., \& AbuBakar, S. (2015). Practices of Dengue Fever Prevention and the Associated Factors among the Orang Asli in Peninsular Malaysia. PLOS Neglected Tropical Diseases, 9(8), e0003954. https://doi.org/10.1371/journal.pntd.0003954 
Diaz-Quijano, F. A., Martínez-Vega, R. A., Rodriguez-Morales, A. J., Rojas-Calero, R. A., Luna-González, M. L., \& Díaz-Quijano, R. G. (2018). Association between the level of education and knowledge, attitudes and practices regarding dengue in the Caribbean region of Colombia. BMC Public Health, 18(1), 143. https://doi.org/10.1186/s12889-018-5055-Z

Elsinga, J., Van Der Veen, H. T., Gerstenbluth, I., Burgerhof, J. G. M., Dijkstra, A., Grobusch, M. P., ... Bailey, A. (2017). Community participation in mosquito breeding site control: An interdisciplinary mixed methods study in Curaçao. Parasites and Vectors, 10(1). https://doi.org/10.1186/s13071-017-2371-6

Fauziah, N., Rahayu, U., \& Thohari, I. (2019). PERILAKU 3M BAGI PENGHUNI RUMAH MEMPENGARUHI KEJADIAN PENYAKIT DEMAM BERDARAH DENGUE. GEMA LINGKUNGAN KESEHATAN, 17(1).

Glanz, K., Rimer, B. K., \& Viswanath, K. (2015). Health Behavior: Theory, Research, and Practice, 5th Edition. John Wiley \& Sons.

Hastuti, N. M., Dharmawan, R., \& Indarto, D. (2017). Sanitation-Related Behavior, Container Index, and Their Associations With Dengue Hemorhagic Fever Incidence in Karanganyar, Central Java. MULTISECTORAL ACTION TO COMBAT REGIONAL AND SOCIAL INEQUITIES IN HEALTH, 2(2), 99. https://doi.org/10.26911/theicph.2017.018

Higa, Y. (2011). Dengue Vectors and their Spatial Distribution. Tropical Medicine and Health, 39(4SUPPLEMENT), S17-S27. https://doi.org/10.2149/tmh.2011-S04

Kumaran, E., Doum, D., Keo, V., Sokha, L., Sam, B. L., Chan, V., ... Hustedt, J. (2018). Dengue knowledge, attitudes and practices and their impact on community-based vector control in rural Cambodia. PLoS Neglected Tropical Diseases, 12(2), e0006268. https://doi.org/10.1371/journal.pntd.0006268

Leslie, T. E., Carson, M., Coeverden, E. van, De (c) Poltekkes Kemenkes Jakarta I Jl. Wijaya Kusuma No. 47-48 Cilandak Jakarta Selatan, Indonesia email: jurnalquality@poltekkesjakarta1.ac.id
Klein, K., Braks, M., \& Krumeich, A. (2017). An analysis of community perceptions of mosquito-borne disease control and prevention in Sint Eustatius, Caribbean Netherlands. Global Health Action, 10(1), 1350394. https://doi.org/10.1080/16549716.2017.1350394

Nazareth, T., Teodósio, R., Porto, G., Gonçalves, L., Seixas, G., Silva, A. C., \& Sousa, C. A. (2014). Strengthening the perception-assessment tools for dengue prevention: a cross-sectional survey in a temperate region (Madeira, Portugal). BMC Public Health, 14(1), 39.

https://doi.org/10.1186/1471-2458-14-39

Nivedita. (2016). Knowledge, attitude, behaviour and practices (KABP) of the community and resultant IEC leading to behaviour change about dengue in Jodhpur City, Rajasthan. Journal of Vector Borne Diseases, 53(3), 279-282.

Retrieved from

https://search.proquest.com/docview/183170496 9? accountid $=17242$

Notoatmodjo. (2014). Ilmu Perilaku Kesehatan (2nd ed.). Jakarta: PT. Rineka Cipta.

Patidar, D. (2019). A Descriptive Study to assess The Knowledge regarding Dengue Fever among adults in Urban Slum Area of Mehasana District. Asian Journal of Nursing Education and Research, 9(2), 163-165. https://doi.org/http://dx.doi.org/10.5958/23492996.2019.00033.8

Rakhmani, A. N., Limpanont, Y., Kaewkungwal, J., \& Okanurak, K. (2018). Factors associated with dengue prevention behaviour in Lowokwaru, Malang, Indonesia: a cross-sectional study. BMC Public Health, 18. https://doi.org/http://dx.doi.org/10.1186/s12889018-5553-z

Salawati, L. (2018). Hubungan pemberantasan sarang nyamuk dengan keberadaan jentik di Kecamatan Jaya Baru Banda Aceh Tahun 2017. Medicus Darussalam, Vol. 1 No., 18-25.

Shamseer, L., Moher, D., Clarke, M., Ghersi, D., Liberati, A., Petticrew, M., ... PGroup, T. ISSN 2655-2434

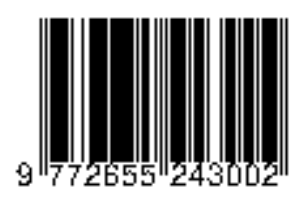


(2016). Preferred reporting items for systematic review and meta-analysis protocols (PRISMAP) 2015: elaboration and explanation. BMJ, 354, i4086. https://doi.org/10.1136/bmj.i4086

Siddiqui, T. R., Ghazal, S., Bibi, S., Ahmed, W., \& Sajjad, S. F. (2016). Use of the Health Belief Model for the Assessment of Public Knowledge and Household Preventive Practices in Karachi, Pakistan, a Dengue-Endemic City. PLoS Neglected Tropical Diseases, 10(11). https://doi.org/10.1371/journal.pntd.0005129

Suwanbamrung, C., Thoutong, C., Eksirinimit, T., Tongjan, S., \& Thongkew, K. (2018). The use of the "Lansaka Model" as the larval indices surveillance system for a sustainable solution to the dengue problem in southern Thailand. PLoS ONE, 13(8).

https://doi.org/10.1371/journal.pone.0201107

Udayanga, L., Gunathilaka, N., Iqbal, M. C. M., Lakmal, K., Amarasinghe, U. S., \& Abeyewickreme, W. (2018). Comprehensive evaluation of demographic, socio-economic and other associated risk factors affecting the occurrence of dengue incidence among Colombo and Kandy Districts of Sri Lanka: a cross-sectional study. Parasites \& Vectors, 11. Retrieved from https://search.proquest.com/docview/210922039 1 ? accountid $=17242$

Vannavong, N., Seidu, R., Stenström, T. A., Dada, N., \& Overgaard, H. J. (2017). Effects of sociodemographic characteristics and household water management on Aedes aegypti production in suburban and rural villages in Laos and Thailand. Parasites and Vectors, 10(1). https://doi.org/10.1186/s13071-017-2107-7

WHO.int. (2012). Global strategy for dengue prevention and control 2012-2020. Retrieved from https://www.who.int/denguecontrol/978924150 4034/en/

WHO. (2012). Global strategy for dengue prevention and control 2012-2020. Retrieved from https://apps.who.int/iris/handle/10665/75303

WHO. (2017). Global Vector Control Response 2017 - 2030: A strategic approach to tackle vectorborne diseases. Who, 0-3. Retrieved from http://www.who.int/vectorcontrol/publications/WHO_HTM_GVCR_2017. $01 / \mathrm{en} /$

Xu, J. W., Liu, H., Ai, Z., Yu, Y., \& Yu, B. (2019). The shan people's health beliefs, knowledge and perceptions of dengue in eastern shan special region iv, Myanmar. PLoS Neglected Tropical Diseases, 13(6). https://doi.org/10.1371/journal.pntd.0007498 